of the Memorie della Sociela degli Spettroscopisli Ilaliani, Signor Antonio Sauve describes a new form of spectroscope which he has devised and calls the "Filtro Spettroscopico."

This instrument enables an observer to view directly, or to photograph, the monochiromatic image of any object which emits-light of the desired ware-length.

Among the various observations for which the author suggests the instrument may be used, he includes the observing of prominences and other solar phenomena, and claims the following advantages for his method over the methods now practised :-(1) The prominences on the whole of the solar disc may be observed visually, and (2) the surface may be observed, visually or photographically, as a whole, instead of having to be taken in sections as is done at present.

Report of the United States Naval ObServatory.This comprehensive report deals with the work done during the fiscal year ending June 30,1902 , and is full of interesting descriptions of the methods employed and the results obtained.

A large diurnal temperature change in the azimuth constant of the 6-inch transit circle has been eliminated by substituting brick and Portland cement piers for the marble piers on which the instrument formerly rested.

With the 26 -inch equatorial, important work has been done in determining the diameters of the planets and their satellites, and, by comparing the diameters obtained at night-time with those obtained at twilight, the constants of the variations due to irradiation have been determined. The results are given in a complete and interesting table. The value for irradiation in the case of Mars varies from $0^{\prime \prime} \cdot 70$ when the planet is in aphelion to $\mathrm{I}^{\prime \prime} \mathrm{O} 2$ when it is in perihelion, and should, therefore, always be taken into account in observations made at different epochs.

During the year, photographs of the sun were obtained with the 40-feet photoheliograph on 200 days, and these showed the presence of spots on 45 days. Although the average number of spots for the whole year is less than during the previous year, the average frequency from October to July is slightly greater, thus indicating that the sun-spot minimum has probably been passed.

Reports on the 12 -inch equatorial, the prime vertical transit instrument and 5 -inch altazimuth, the magnetic and meteor. ological sections, and several other instruments and departments are also given in detail.

A NEW I 8-inch refractor is being made by Messrs. Alvan Clark and Sons for Amherst College Observatury.

WE are pleased to learn that the recent fire at Yerkes did no injury to the 40 -inch refractor, but some damage was done in the coelostat room.

\section{FORESTRY IN THE UNITED STATES OF AMERICA.}

- WENTY years ago, the people of the United States did not trouble themselves much about their forests. It was said that enormous areas were stocked $\mathrm{vith}$ an inexhaustible amount of timber and fuel. Since then a great change has taken place. It has gradually been ascertained that, although the total forest area is estimated at about 700 million acres, the average stand does not amount to more than about five tons per acre, which is equivalent to about one-tenth of what it would be in systematically managed forests; in other word, the stand of iimber in the United States forests is equal to the stand in about 70 million acres of forests such as are to be found in Germany and a great portion of France. Since it has been ascertained that the actual cuttings of timber in the United States exceed already 100 million tons a year, it fullows that the present stand must be used up in about thirty years. Nor is the quantity re. moved annually from the forests replaced by new growth, as the latter has been estimated to amount to about 75 million tons. Moreover, it must not be forgotten that the annual forest fires destroy enormous quantities of material.

As already stated, these matters began to attract attention some twenty years ago. Thoughtful people wrote about them, societies were formed, information collected and made available to the general public. The State Governments issued regula. tions so as to prevent further destruction by fire, and they established certain Stale parks. Nor did the Federal Govern. ment neglect the matter. A Chief of the Forestry Division of the Agricultural Department was appointed, Mr. Fernow, who sot together statistics and spread sound ideas regarding the rational treatment of forests. He was succeeded, a few years ago, by Mr. Gifford Pinchot. The latter went, about fourteen years ago, to study forestry in Germany and France. After his return to America, he set up in New York as a " consulting forester" (though a very wealthy young gentleman). Mr. George Vanderbilt engaged him to manage his forests at Bittmore, now amounting to more than 100,000 acres, having for his object to see whether systematic forestry can be made to pay in the States. In this post Mr. Pinchot was succeeded, about eight years agu, by Dr. Schenck, a first-class German forester.

When Mr. Fernow left his post at Washington, he hecame Professor and Dean of the Faculty of Forestry at Cornell University, endowed by the State of New York with money, and 30,000 acres of forest lands in the Adirondacks for systematic management and practical instruction. Soon after Mr. Gifford Pinchot took up the post at Washington, he and his family presented Yale University with the sum of $30,000 /$. for the purpose of endowing a second forest school in connection with the University; they also established a summer school for the study of forestry by those who could not afford to proceed to a regular degree at the University. According to the report for 1901-2, there were thirty-one students of forestry at Yale University and twenty-seven attending the summer school.

At Biltmore, Dr. Schenck has established a third forest school, where, on October I, 1902, sixteen students were in attendance. I had on two occasions the pleasure of conducting students of this school through some of the most interesting forests of south Germany (seven in 1900 and six in 1902), these young gentlemen having, at the conclusion of their course at Billmore, come to see something of systematic forest management in Europe.

Apart from the above three higher schools, forestry is now taught at about forly other educational establishments in the United States. In this way, quite a respectable number of well; trained forest experts has become available, in addition to about half-a-dozen young men who followed Mr. Pinchot's plan and studied in Germany.

The Federal Government has, by degrees, inaugurated a systematic forest policy, progress having been specially rapid since Mr. Pinchot became head of the Forestry Bureau. An area of 46 million acres of Government land has been declared (chiefly in Mr. Cleveland's time) "reservations," by Presidential proclamation. These areas are situated in the west. And now President Roosevelt has sent a message to the Senate and House of Representatives recommending a national forest reserve of considerable extent in the Southern Appalachian region, this measure being, as he states, "an economic need of prime im. portance to the welfare of the south, and bence to that of the nation as a whole."

Another matter vigorously taken up by the Bureau of Forestry is the preparation of rational working plans for private forests. A considerable number of field assistants have been engaged, who are sent out to prepare working plans for the forests of such private proprietors as apply for them. So great has been the demand in this respect that, although last year plans were prepared for more than one million acres, the field assistants could deal with only abuut one-tenth of the applications received at the head office.

All the while, the cullection of statistics and dissemination of useful information proceeds at a most rapid rate. In this respect I may mentiun that $I$ have during the last three months received the following reports and pamphlets :-

(1) "The Timber Resources of Nebraska," by W. Hall, Superintendent of Tree Planting, Bureau of Forestry.

(2) "Grazing in the Forest Reservec," by Filibert Roth, of the United States Department of the Interior, in charge of the work in the Government forest reserves.

(3) "A Working Plan for Southern IIardwoods and its Results," by J. Foley, Field Assistant, Bureau of Forestry.

(4) "A History of the Lumber Industry in the State of New York," by Colonel W. Fox, Superintendent of Forests, New York State.

(5) "The Western Hemlock," by G. E. Allen, Field Assistant, Bureau of Forestry.

(6) The above-mentioned message by President Roosevelt, transmitting a magnificent volume of reports on the forests, rivers and mountains of the Southern Appalachian region.

No. 1737 , voL. 67] 
(7) "First Book of Forestry," by Filibert Roth. This little elementary book is most charmingly written, giving in simple terms, and in an attractive form, the first principles of forestry. Although the illustrations are taken from species growing in the United States, I can strongly recommend the little book (published by Ginn and Company, pp. 26r, price $3 s .6 d_{\text {.) }}$ to landed proprietors and foresters in this country.

I have no doubt that these publications form only part of those which have lately appeared. All show signs of a good grasp of the subject, and prove the vigour with which it has been taken up. Asalready indicated, the forests of the United States are at present worked under a heavy deficit, as compared with production. This deficit will increase with the growth of the population and the further development of the industries of the country, and this will go on until a sufficient area of forests has been placed under systematic management. That measures to bring this about have not been taken a day too soon will be evident when it is considered what the requirements of the country are. Not only are enormous quantities of wood fuel wanted for a popula. tion of some 80 million peoples, but timber in proportion is required for pulp wood, posts, railway ties, poles for telegraphs and for piling, mining timber, ship timber, cooperage and wagon timber, lumber generally, and for many other purposes. To give an idea of what the total requirements may amount to, I shall pick out one or two items. There are upwards of 200,000 miles of railways in the States, which require annually some 70 million railway ties. To keep up this supply, some 8 to 10 million acres of well-managed forests are wanted. The annual requirements of general lumber are at present estimated at 30 billion feet, board measure, requiring not less than some 100 million acres of forests to keep up the supply. The demands for pulp wood and mining timber are already enormous, and likely to increase. The exports of timber from the States amount to a little more than one million tons a year, and these are already considerably exceeded by imports from Canada.

On the whole, then, the reservations made up to date can be considered only as a moderate beginning in the right direction. To meet the future requirements of the nation, the present area of reservations must be largely increased and they must all be brought under systematic protection and management. How. ever, the people and the Government are evidently determined to do what is necessary, and their efforts up to date bear testimony to the energy with which any question bearing on the general welfare of the nation is taken up and carried through.

Can we in this country not learn a lesson from the above facts, as we have been obliged to do in more than one other respect of late years? Our timber imports have latterly grown very rapidly, far more so than the increase of the population, while the sources of supply are becoming more and more precarious. It is all very well to say that we can pay for the imported timber, but what when the sources of supply fail? And all this time we have some 13 million acres of waste land and some 12 million acres of mountain and heath land used for light grazing in these islands, or a total of 25 million acres which yield a very small return or none at all. One. quarter of that area put under forest and treated in a rational manner would supply all the timber we require (apart from limited quantities of tropical timbers) and keep some 25 million pounds sterling in the country which we now send abroad every year to pay for the imported limber. And how many of the unfortunate unemployed, who are becoming the nightmare of our city authorities, would not find healthy employment in the country if a real effort were made to grow our own timber at home?

W. SCHLICH.

\section{THE ELECTROCHEMICAL SOCIETY.}

I AST March a few of those interested in the advancement of the study of electrochemistry in this country held a meeting in London. After some discussion as to the best means of advancing the object which it had in view, the meeting unanimously agreed to endeavour to form a society of electrochemists. A small committee was then appointed, which, after holding several meetings, sent out circulars to those who it was thought would be interested in the formation of such a society. A considerable number of favourable replies was received, but some who wrote deprecated the idea of adding yet another to the already large number of scientific societies. The committee then approached several existing societies, in order to see whether it might not be possible to work in conjunction with one or other of them. But although the replies received were couched in friendly terms, none of these societies seemed inclined to make any special effort to help forward the movement.

In these circumstances it was decided to call a general meeting of supporters of the movement to inaugurate an Electrochemical Society. By the kind permission of the committee of the Faraday Club, the meeting was held in the club rooms at the St. Ermin's Hotel, on the afternoon of February 4 .

Mr. Swinburne, chairman of the committee, took the chair, and briefly reviewed the circumstances which had brought the meeting together. He emphasised the importance of the electrochemical industry abroad, and pointed out how exceedingly backward we are in this country. $\mathrm{Mr}$. Swan, in a brief speech, then proposed the formation of the society, and said that there was no doubt but that it would be of great scientific and commercial value. $\mathrm{Mr}$. Alexander Siemens seconded the motion, which was carried unanimously.

Mr. Swinburne then read out a list of those who had been nominated by the committee and had expressed their willingness to serve on the council of the society. $\mathrm{Mr}$. Swan, F.R.S., was elected president, the vice-presidents being Lord Kelvin, Prof. Crum Brown, F.R.S., Sir Oliver Lodge, F.R.S., Lord Rayleigh, Mr. Ludwig Mond, F.R.S., $\mathrm{Mr}$. Alexander Siemens and Mr. J. Swinburne. The committee's recommendations were unanimously endorsed, and after a short discussion, and a vote of thanks to the committee of formation, the meeting separated.

The youngest of scientific societies in the country started off with a promised membership of 150 . There is, however, very little doubt but that in a short time many more, who have only been waiting for the movement to become an assured success, will join. Already since circulars calling the meeting were sent out, several who in the first place refused their support have sent in their names for membership.

The science of electrochemistry, which was initiated in this country through the splendid work of Davy and Faraday, has been allowed to languish, and but little attention has been paid to its great advancement abroad. In Germany a flourishing society, which issues a weekly journal, has been in existence for more than eight years. The Americans have a very vigorous society, which was established last year. The British society has been established with the object of advancing both pure and applied science. One is of ten met by the cry that electrochemical industry is all very well in countries where here is plenty of cheap waterpower, but that it will never be a success when you have to depend upon coal as an initial source of energy. But there is such a source of power as the Mond gas, and gas engines are every day becoming more perfect. Again, coal is cheaper in this country than in most places where there is an abundance of water-power. In some directions we may be handicapped; to a large extent this is due to our own inertness--our great chemist, Faraday, laid the foundationstone of electrochemical science--we have left it to others to build thereon. But the building is not complete; indeed, it may require to be partially pulled down and rebuilt. The Electrochemical Society has been formed to rehabilitate the science in this country, and its promoters look forward with the sanguine hope that when the scientific history of the next decade is written, British discoveries and inventions in the domain of electrochemistry will not be behind those of any other country.

All interested in electrochemistry and physical science and who are willing to help forward this society should send in their names to Mr. F. S. Spiers, Grosvenor Mansions, Victoria Street, Westminster.

\section{AGRICULTURAL NOTES.}

$\mathrm{I} \mathrm{N}$ a shilling pamphlet pablished at the offices of the Mark Lane Express, Mr. W. J. Malden, of the Colon al College, Hollesley Bay, discusses the m srits of ten new " poratoes with money in them." Hundreds of new varieties have been raised in the past few years; but nearly all of tho e named in the pamphlet have been produced by one grower--Mr. Findlay, of Markinch - and this fact indicates that to raise valuable new No. 1737 , vOL. 67$]$ 